\title{
Venous congestive myelopathy: a mimic of neoplasia
}

\author{
Fausto J Rodriguez ${ }^{1}$, Brian A Crum², William E Krauss ${ }^{3}$, Bernd W Scheithauer ${ }^{1}$ and \\ Caterina Giannini ${ }^{1}$ \\ ${ }^{1}$ Department of Laboratory Medicine and Pathology, Mayo Clinic, Rochester, MN, USA; ${ }^{2}$ Department of \\ Neurology, Mayo Clinic, Rochester, MN, USA and ${ }^{3}$ Department of Neurosurgery, Mayo Clinic, Rochester, \\ $M N, U S A$
}

\begin{abstract}
Venous congestive myelopathy is a progressive disorder frequently associated with arteriovenous fistulas, usually dural. By causing diffuse spinal cord enlargement and enhancement on imaging, it may simulate a neoplasm and prompt a biopsy. We evaluated the biopsy findings in seven such patients $(M=5, F=2$, mean age $59 \pm 11$ years) who presented variably with progressive lower extremity weakness $(86 \%)$, bowel and bladder dysfunction $(86 \%)$, sensory changes $(86 \%)$ or pain $(29 \%)$. Preoperative magnetic resonance imaging showed spinal cord enlargement with T2-hyperintensity $(86 \%)$ and contrast enhancement $(57 \%)$ at the cervical $(14 \%)$, thoracolumbar $(57 \%)$, and/or conus medullaris $(57 \%)$ level. Prebiopsy spinal angiogram, performed in two patients, was negative. Spinal cord biopsy showed architecturally distorted parenchyma with gliosis and thick hyalinized vessels $(100 \%)$, variable myelin loss $(71 \%)$, mild glial atypia $(57 \%)$, hemosiderin deposition $(71 \%)$, Rosenthal fibers $(43 \%)$, vascular thrombosis $(29 \%)$, and necrosis $(29 \%)$, features highly suggestive of venous congestive myelopathy. Postbiopsy spinal angiograms were performed in five patients. A dural arteriovenous fistula was identified by selective angiography in three patients, including the two with a negative preoperative angiogram. Additional postbiopsy angiographic studies in two patients were negative, and two patients were followed up without angiography. Mean follow-up after biopsy was 13.6 months. Histologic changes characteristic of venous congestive myelopathy may be seen in spinal cord biopsies with or without an associated fistula. Recognition of this entity by surgical pathologists is important, leading to the correct identification of a non-neoplastic lesion as well as of a surgically treatable disease.

Modern Pathology (2005) 18, 710-718, advance online publication, 3 December 2004; doi:10.1038/modpathol.3800350
\end{abstract}

Keywords: venous congestive myelopathy; Foix-Alajounine syndrome; spinal dural arteriovenous fistula; spinal cord tumor; progressive myelopathy

The diagnosis of spinal cord biopsies can be challenging. In addition to tumors, a variety of non-neoplastic lesions, including demyelination and vascular malformations, may cause diffuse enlargement of the spinal cord. The resemblance by imaging to a primary intramedullary tumor may prompt a biopsy. Due to the high risk of morbidity, only small biopsy samples are frequently obtained, amplifying the diagnostic difficulties.

Venous congestive myelopathy often results from impaired venous outflow secondary to a spinal arteriovenous fistula. ${ }^{1-4}$ The primary vascular pathology often lies outside the spinal cord. The secondary changes occurring in the spinal paren-

Correspondence: Dr C Giannini, MD, PhD, Department of Laboratory Medicine and Pathology, 200 First Street SW, Mayo Clinic, Rochester, MN 55905, USA.

E-mail: Giannini.Caterina@Mayo.edu

Received 25 August 2004; revised 7 October 2004; accepted 10 October 2004; published online 3 December 2004 chyma, however, histologically can mimic an intraspinal vascular malformation or even a neoplasm. The most common location of spinal arteriovenous fistulas, accounting for $56 \%$ of cases, is dural, located by the root sleeve. ${ }^{5}$ Foix-Alajouanine syndrome, also called subacute necrotizing myelopathy or angiodysgenetic necrotizing myelopathy, was the old term used to describe this progressive myelopathy. Clinically, it was characterized by progressive paraparesis, pain, sensory abnormalities of the lower limbs, and alterations in bowel, bladder, and sexual function. ${ }^{6-8}$ The pathology of this syndrome, especially of the most severe cases, has been well characterized in postmortem studies. It includes an increased number of small hyalinized vessels, gliosis, vascular thrombosis, hemosiderin deposition, hypoxic/ischemic changes, and coagulative necrosis of the spinal cord. ${ }^{8-10}$ The spinal dural arteriovenous fistula usually localizes to the lower thoracic and/or lumbosacral levels; cervical cord involvement is rare. ${ }^{11-13}$ In the typical spinal dural 
arteriovenous fistula, engorged tortuous vascular channels are identified in the subarachnoid space predominantly on the dorsal aspect of the cord, a consequence of the impaired spinal venous drainage. ${ }^{2,11,12}$ Venous congestive myelopathy can also be caused by arteriovenous fistulas occurring intradurally and involving the perimedullary space, or rarely extradurally. ${ }^{2}$ Similar pathologic changes have also been rarely reported in the absence of a demonstrable fistula or of abnormal spinal surface vessels. ${ }^{13-15}$

Magnetic resonance imaging (MRI), by demonstrating the presence of enlarged, contrast-enhancing tortuous vessels in the subarachnoid space, spinal cord swelling and enhancement, and increased spinal cord signal on T2-weighted images may prompt consideration of the diagnosis of venous congestive myelopathy. ${ }^{16-18}$ However, these characteristic changes are not always apparent and, in the absence of a demonstrable spinal dural arteriovenous fistula, the preoperative differentiation from a tumor may be impossible. ${ }^{16}$ Even when clinically suspected, a spinal dural arteriovenous fistula may be difficult to demonstrate unless complete selective digital subtraction spinal angiography is performed..$^{9}$

The surgical pathologist may encounter spinal cord biopsies from these patients; thus it is necessary to be familiar with the histologic features of venous congestive myelopathy to avoid a misdiagnosis of neoplasm and to identify a surgically treatable condition. ${ }^{11,12,20-23}$ Herein, we report the clinical/histopathologic findings and follow-up in a group of seven patients who underwent spinal cord biopsy with a preoperative clinical and radiographic diagnosis of neoplasia. All were found to have histologic findings characteristic of venous congestive myelopathy and suggestive of an associated spinal dural arteriovenous fistula.

\section{Materials and methods}

\section{Patients}

This study was approved by and undertaken in accordance with the regulations of the Mayo Foundation Institutional Review Board. Review of the records of the department of pathology identified 11 patients who underwent spinal cord biopsy between 1994 and 2003 to rule out a tumor, and in whom the final pathology report was suggestive of venous congestive myelopathy as associated with an arteriovenous fistula. Four patients were excluded for lack of adequate clinical and radiologic information. Of the remaining seven, three patients were evaluated at Mayo Clinic and four were identified in the consultation files of one of the authors (BWS). Five patients were male and two female. Their mean age was 59 years ( $S D \pm 11$; range $31-73$ years) (Table 1). Clinical notes, neuroimaging studies, and operative reports were carefully reviewed. Preoperative imaging studies included MRI of the spine in all cases, conventional spinal angiogram in two, and computed tomography myelogram in three.

\section{Pathology}

Hematoxylin- and eosin-(H\&E) stained slides obtained from formalin-fixed paraffin-embedded tissue were examined in all cases. Each was assessed for the presence of the following characteristics: increased vascular hyalinization, gliosis, glial atypia, vascular thrombosis or calcification, hemosiderin deposits, Rosenthal fibers, myelin loss, and necrosis. Histochemical and immunohistochemical stains obtained in selected patients included: LFB/ PAS, Masson's trichrome, glial fibrillary acidic protein (Dako 1:800), neurofilament protein (Dako 1:75), KP-1 (Dako 1:200), MIB-1 (Dako 1:800), and p53 protein (Dako 1:200) immunostains.

\section{Results}

\section{Clinical Findings}

Relevant clinical data is summarized in Table 1. All patients originally presented with subacute neurologic symptoms. Preoperative MRI showed spinal cord enlargement with T2-hyperintensity $(86 \%)$ and contrast enhancement (57\%). In one thoracic level case (case 7), T2-hyperintensity with no definite spinal cord enlargement was seen. Conventional spinal angiograms were performed in two patients (cases 1 and 3 ); both were negative although one of them was categorized as incomplete upon the second review (case 1). An example of spinal cord enlargement is illustrated in Figure 1 (case 1). In this case, angiography had been prompted by the MRI finding of abnormal vasculature on the posterior surface of the spinal cord, but was negative. In case 3 , no abnormal vasculature was noted either by MRI or intraoperative inspection.

\section{Pathology Findings}

Given their small size, the spinal cord biopsies frequently showed distortion of architecture. Gliosis and mild glial atypia were often seen (57\%) (Figures $2-5$ ). In all cases, there was an increased number of small vessels with markedly hyalinized vascular walls (Figures 2 and 5). There was frequently (71\%) a relative myelin loss as best demonstrated on LFB/PAS (Figure 5b). Neurofilament stains showed axonal loss only in the two cases featuring necrosis. The findings were not those seen in primary demyelination given the following observations: hemosiderin deposition, predominantly perivascular and indicative of previous bleeding, was commonly seen (71\%) (Figures 2b, inset, and 5c). Scattered Rosenthal fibers were present in some 
Table 1 Clinical features

\begin{tabular}{|c|c|c|c|c|c|c|c|c|}
\hline Case & Age/sex & Symptoms & $\begin{array}{l}\text { Duration } \\
\text { (years) }\end{array}$ & Site & Preoperative imaging & Surgical findings & Postoperative imaging & Postoperative follow-up \\
\hline 1 & $60 / \mathrm{M}$ & $\begin{array}{l}\text { Progressive } \\
\text { paraparesis, } \\
\text { bowel/bladder } \\
\text { dysfunction, } \\
\text { sensory changes }\end{array}$ & 7 & Conus & $\begin{array}{l}\text { High T2, cord enlargement, } \\
\text { diffuse enhancement, spinal } \\
\text { angiogram negative }\end{array}$ & Dilated vessels & $\begin{array}{l}\text { Angiogram: T7 dural } \\
\text { arteriovenous fistula }\end{array}$ & $\begin{array}{l}\text { Fistula corrected, } \\
\text { mild improvement in } \\
\text { strength and imaging } \\
\text { changes at } 18 \text { months }\end{array}$ \\
\hline 2 & $38 / \mathrm{F}$ & $\begin{array}{l}\text { Chest and left } \\
\text { arm pain, } \\
\text { paresthesias }\end{array}$ & 5 & Lower C/upper T & $\begin{array}{l}\text { High T2, cord enlargement, } \\
\text { surface enhancement }\end{array}$ & $\begin{array}{l}\text { Cord enlargement, } \\
\text { increased vascularity } \\
\text { at midline }\end{array}$ & Angiogram: no fistula & Stable, at 13 months \\
\hline 3 & $73 / \mathrm{M}$ & $\begin{array}{l}\text { Lower extremity } \\
\text { weakness, } \\
\text { bowel/bladder } \\
\text { dysfunction }\end{array}$ & NA & T6-L2 & $\begin{array}{l}\text { High T2, cord enlargement, } \\
\text { negative CT myelogram, } \\
\text { negative spinal angiogram }\end{array}$ & $\begin{array}{l}\text { Cord enlargement, no } \\
\text { vascular abnormalities }\end{array}$ & $\begin{array}{l}\text { Angiogram: T5-6 dural } \\
\text { arteriovenous fistula }\end{array}$ & $\begin{array}{l}\text { Fistula corrected Stable } \\
\text { at } 17 \text { months }\end{array}$ \\
\hline 4 & $65 / \mathrm{M}$ & $\begin{array}{l}\text { Progressive } \\
\text { paraparesis, } \\
\text { bowel/bladder } \\
\text { dysfunction, } \\
\text { numbness }\end{array}$ & 0.5 & Lower T/lumbar & $\begin{array}{l}\text { High T2 thoracic cord and } \\
\text { conus, enhancement, } \\
\text { enlargement }\end{array}$ & Not available & $\begin{array}{l}\text { Angiogram: T10 dural } \\
\text { arteriovenous fistula }\end{array}$ & $\begin{array}{l}\text { Fistula corrected, mild } \\
\text { improvement } 1 \text { month } \\
\text { after correction of fistula }\end{array}$ \\
\hline 5 & $62 / \mathrm{M}$ & $\begin{array}{l}\text { Paraparesis, } \\
\text { pain, } \\
\text { bladder/bowel } \\
\text { dysfunction, } \\
\text { sensory change }\end{array}$ & 2 & Conus & $\begin{array}{l}\text { High T2, cord enlargement, } \\
\text { peripheral enhancement, } \\
\text { myelogram, normal }\end{array}$ & $\begin{array}{l}\text { Cord enlargement, } \\
\text { discoloration, no } \\
\text { abnormal vessels }\end{array}$ & $\begin{array}{l}\text { Angiogram: not } \\
\text { performed MRI: } \\
\text { improved }\end{array}$ & $\begin{array}{l}\text { Clinical improvement } \\
\text { at } 18 \text { months }\end{array}$ \\
\hline 6 & $61 / \mathrm{M}$ & $\begin{array}{l}\text { Progressive } \\
\text { paraparesis, } \\
\text { bladder } \\
\text { incontinence, } \\
\text { constipation, } \\
\text { sensory loss }\end{array}$ & NA & T-L/conus & $\begin{array}{l}\text { High T2,cord enlargement, } \\
\text { no enhancement }\end{array}$ & Not available & $\begin{array}{l}\text { Negative spinal angiogram } \\
\text { MRI:stable }\end{array}$ & $\begin{array}{l}\text { Completely paraplegic } \\
\text { at } 26 \text { months }\end{array}$ \\
\hline 7 & $54 / F$ & $\begin{array}{l}\text { Paraparesis, } \\
\text { bowel/bladder } \\
\text { dysfunction, } \\
\text { sensory changes }\end{array}$ & 2.3 & $\mathrm{~T} 6-7$ & $\begin{array}{l}\text { High T2, no } \\
\text { enlargement, no } \\
\text { enhancement CT } \\
\text { myelogram: no abnormal } \\
\text { vessels }\end{array}$ & $\begin{array}{l}\text { Abnormal } \\
\text { intramedullary } \\
\text { tissue, no } \\
\text { abnormal vessels }\end{array}$ & Not performed MRI: stable & $\begin{array}{l}\text { Slight clinical } \\
\text { improvement } 2 \text { months } \\
\text { postoperatively }\end{array}$ \\
\hline
\end{tabular}



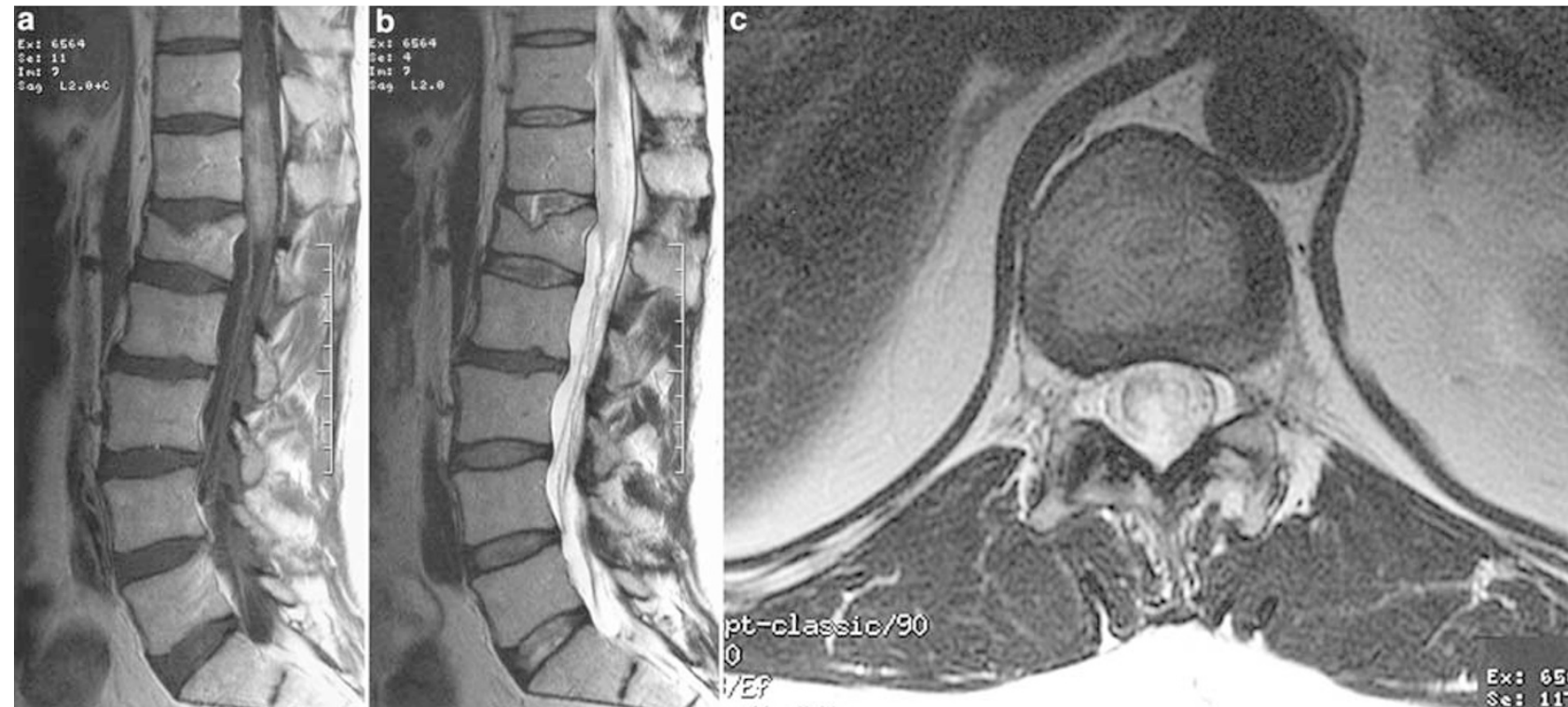

Figure 1 Patient 1: (a) Sagittal T1-weighted MRI after administration of intravenous gadolinium showing enhancement and enlargement of the conus medullaris. Also seen are serpiginous vessels on the dorsal spinal cord and cauda equina. (b) Sagittal T2-weighted MRI similarly showing enlargement and hyperintensity of the conus medullaris. (c) Axial T2-weighted MRI of the lower lumbar spinal cord displaying enlargement and hyperintensity.

a

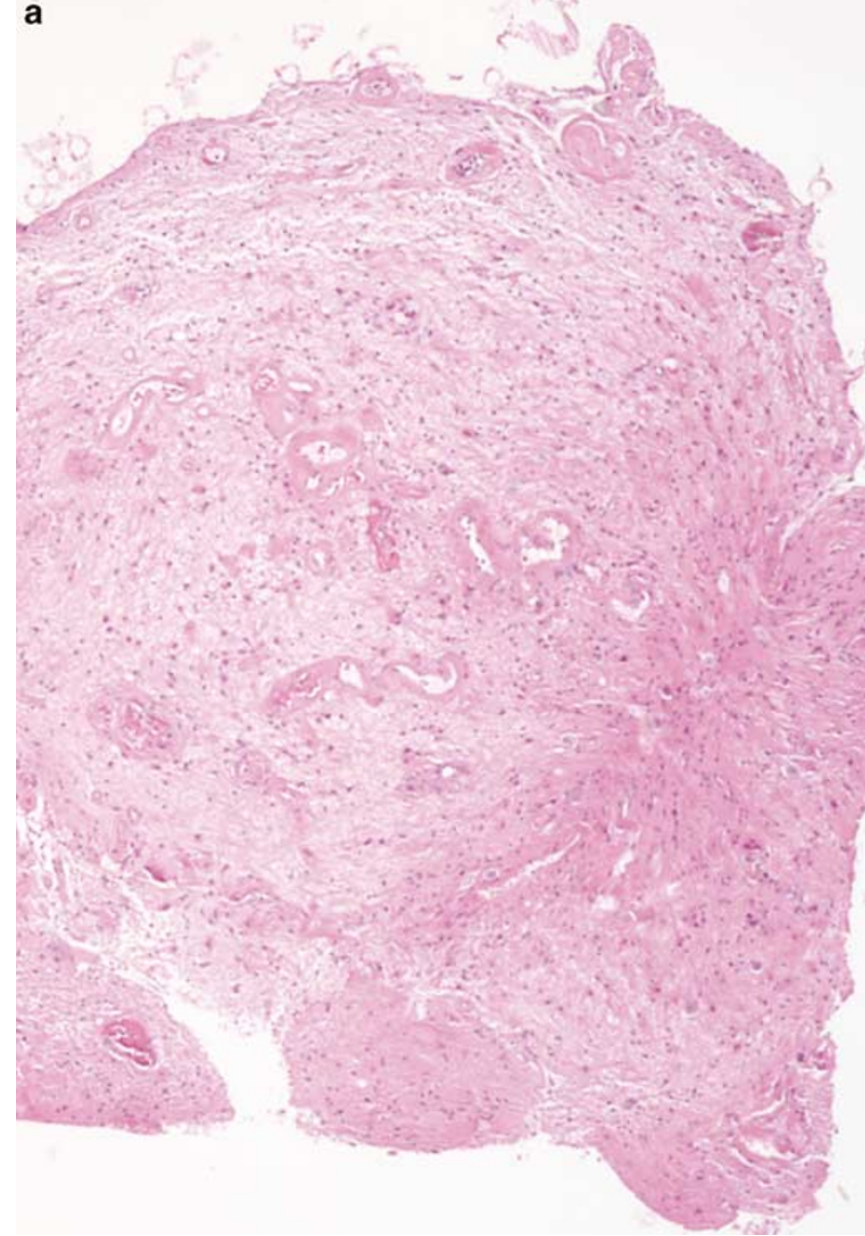

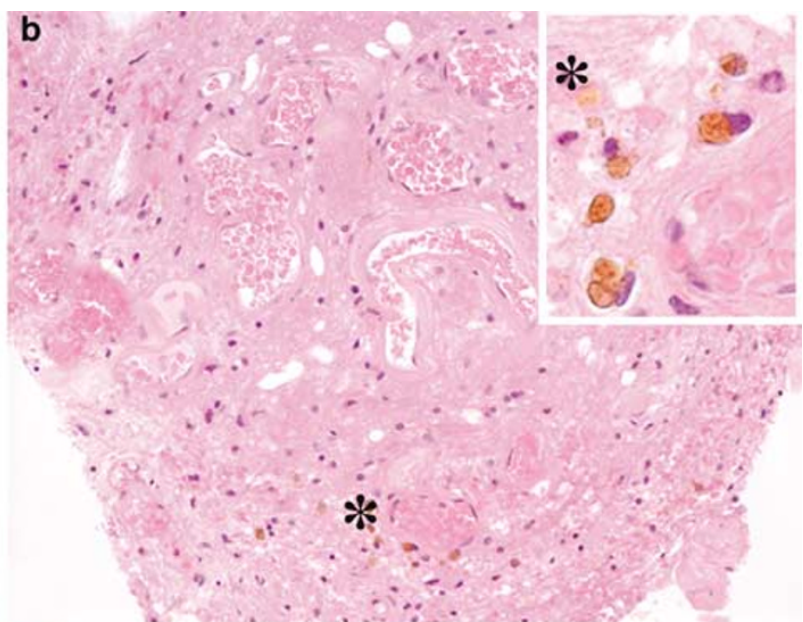

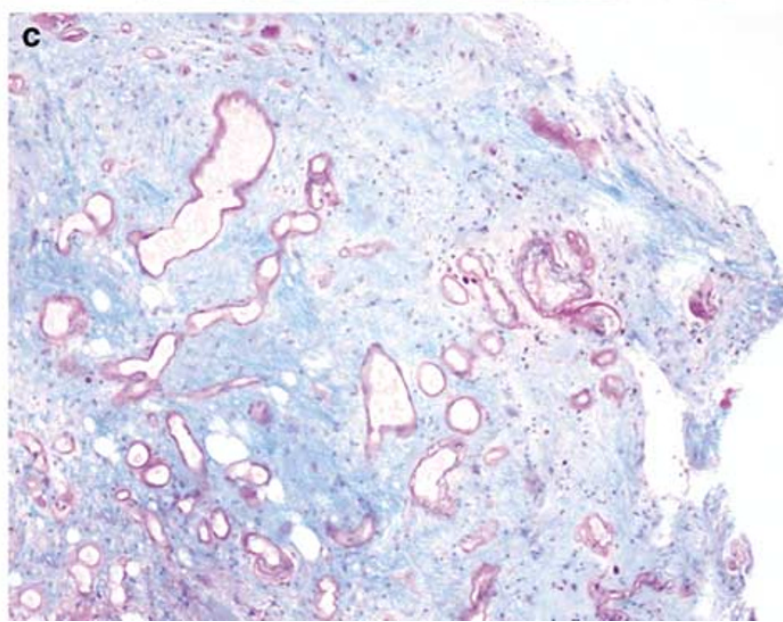

Figure 2 (a) Low-power photomicrograph of spinal cord biopsy showing conspicuous hyalinized vessels in patient 1 (H\&E, $\times 40)$. (b) Prominent hyalinized vessels in patient 3 and hemosiderin-laden macrophages (inset) (H\&E, $\times 100, \times 600)$. (c) Low-power photo demonstrating thickened vessels in patient $3(\mathrm{LFB} / \mathrm{PAS} \times 100)$. 

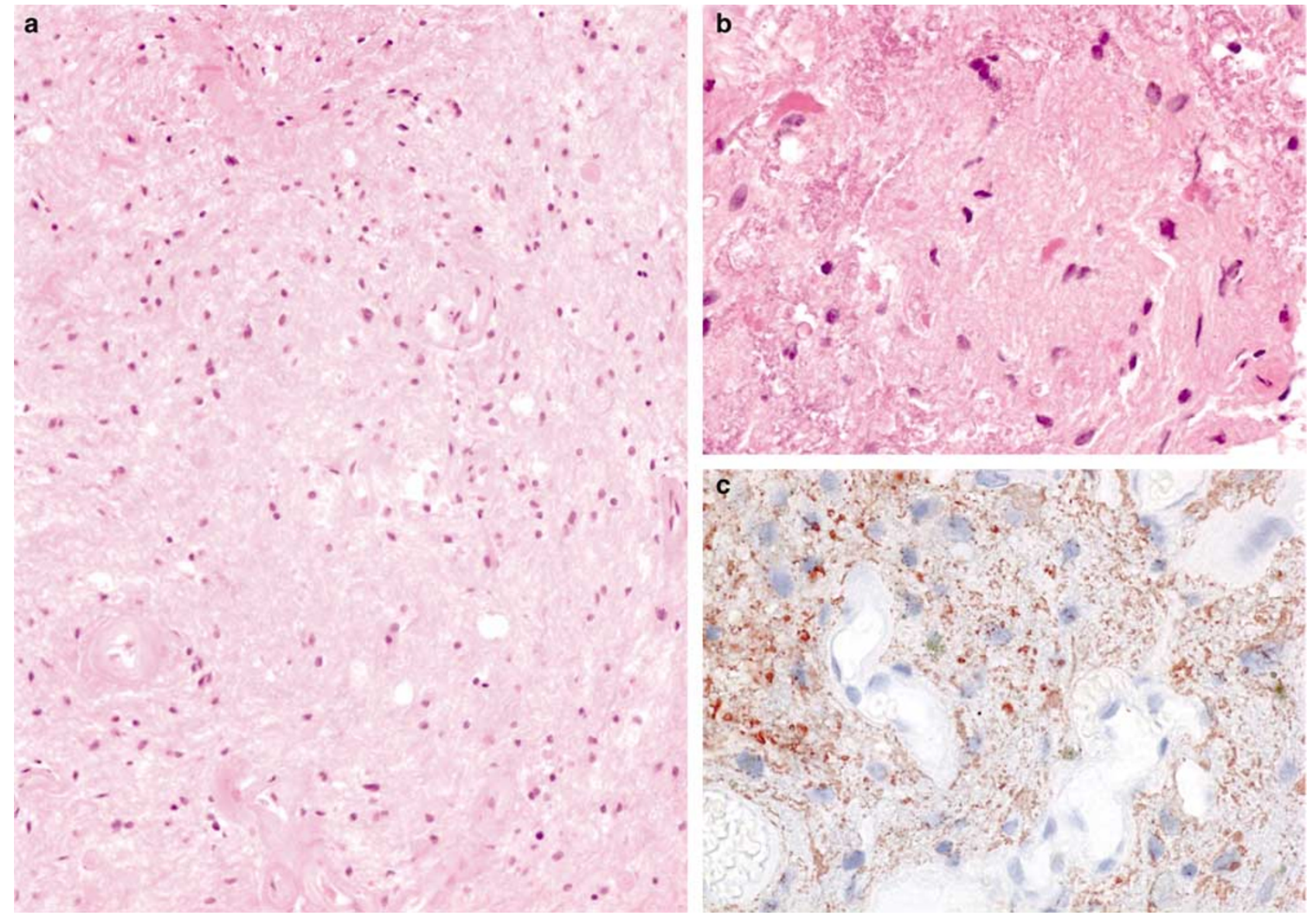

Figure 3 Patient 3: (a) Medium-power photomicrograph showing mild hypercellularity (H\&E, $\times 200$ ). (b) Higher power view demonstrating rosenthal fibers $(\mathrm{H} \& \mathrm{E}, \times 600)$. (c) GFAP immunohistochemical stain highlights perivascular gliosis $($ Dako 1:800, $\times 400)$.

cases (43\%) (Figures 3b and 5e). Vascular thrombosis and necrosis were seen each in two cases $(29 \%)$ (Figure 4). Vascular thrombosis was the only feature seen exclusively in patients found subsequently to have a spinal dural arteriovenous fistula (two of three patients). Vessel wall calcification was not observed in any of the cases. The distribution of these various findings is summarized in Table 2.

\section{Clinical Follow-up}

The histologic changes noted above suggested the possibility of an associated spinal dural arteriovenous fistula. Indeed, this was subsequently identified in three patients (cases 1, 3 and 4) by selective spinal angiography (ie injection of all thoracic intercostal arteries). This included the two patients (cases 1 and 3) with previously negative conventional spinal angiograms. In case 4, upon review of the histologic findings, consistent with venous congestive myelopathy, a magnetic resonance angiogram suggested a fistula in the vicinity of T9 or T10 on the right, later confirmed by selective spinal angiography (Figure 6). Two patients (cases 2 and 6) also underwent further angiographic studies. Case 2 had been referred with a diagnosis of astrocytoma. Upon review of the biopsy findings, neoplasia was excluded. Considering, in addition, the intraoperative description of increased vascularity over the posterior surface of the cervical cord, both intracranial and complete spinal angiograms were obtained; no arteriovenous fistula was identified. The patient was followed clinically without further intervention, and no clinical deterioration occurred. Case 6 underwent spinal and abdominal angiography, as well as a computed tomography myelogram; all were negative.

In cases 5 and 7, further angiographic studies were not pursued and the patients were followed with spinal MRI only.

The mean clinical follow-up time after spinal cord biopsy of all patients was 13.6 months (range 1-26 months). The three patients with a spinal dural arteriovenous fistula underwent surgical disconnection of the fistulas. One of these patients experienced mild clinical and radiographic improvement, while two remained stable. Of the four patients in whom a fistula could not be demonstrated, one patient showed significant clinical and radiographic 

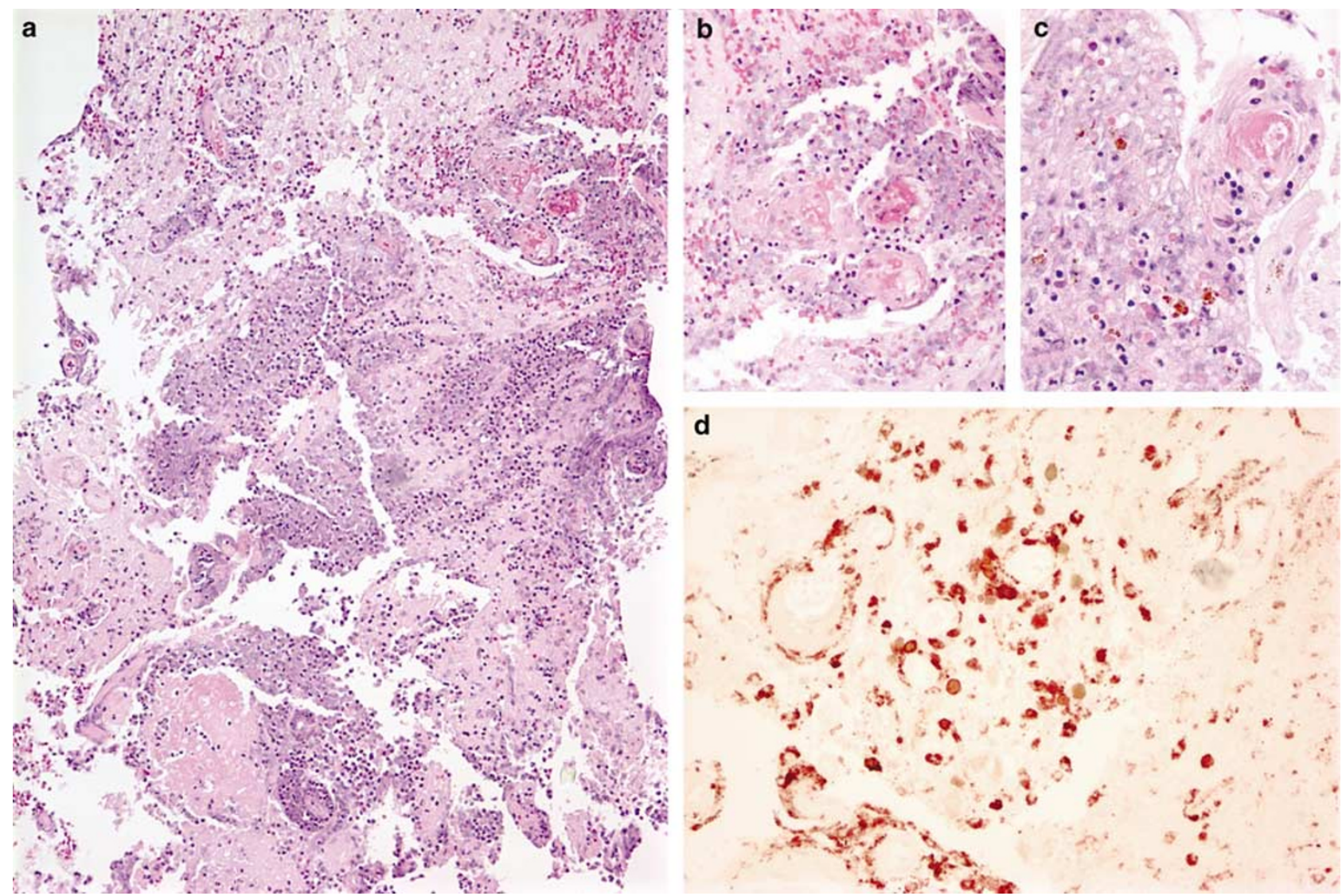

Figure 4 Patient 4: (a) Low-power photomicrograph demonstrating prominent coagulative necrosis (H\&E, $\times 40)$. High-power views showing microvascular thrombosis $(\mathbf{b}, \mathrm{H} \& \mathrm{E}, \times 400)$ and hemosiderin deposition $(\mathbf{c}, \mathrm{H} \& \mathrm{E}, \times 600)$. (d) KP-1 immunohistochemical stain confirms the presence of abundant macrophages (Dako 1:200, $\times 400$ ).

improvement 18 months postbiopsy, one showed slight improvement in bowel and bladder function, one remained stable clinically and radiographically, and one, despite stable MRI findings at 26 months, progressed to complete paraplegia.

\section{Discussion}

The spectrum of histologic changes described in venous congestive myelopathy is quite characteristic of the condition and is important to recognize. The identification in a spinal cord biopsy of these complex changes as reactive is of fundamental importance for two reasons. The first is the exclusion of a diagnosis of neoplasia. The second is the recognition of an often curable lesion.

This constellation of findings has been in fact associated primarily with arteriovenous fistulas, a common group of spinal vascular malformations, historically obscured by a confusing terminology. ${ }^{24-26}$ The most recent classifications of spinal arteriovenous fistulas have emphasized the pathological anatomy of the vascular channels, encompassing all surgical vascular lesions and providing a clear rationale to guide treatment. ${ }^{12,27-29}$ We find particularly simple and useful the distinction of arterio- venous fistulas as dural, intradural (perimedullary and intramedullary), and extradural based on the location of the fistula. ${ }^{26}$ The most common of these, spinal dural arteriovenous fistula, as well as the less frequently encountered perimedullary and epidural fistula all can cause a progressive myelopathy. ${ }^{2,30}$ Intramedullary fistulas, which are rare, often present with hemorrhage. ${ }^{12}$

The underlying pathophysiologic mechanism of the myelopathy induced by arteriovenous fistulas is now believed to involve passive venous congestion of the cord, ${ }^{1-4,31}$ because arterial blood originating from the fistula enters the perimedullary venous plexus, a valveless system, increasing pressure and impairing normal drainage from the cord parenchyma. The preferential involvement of the distal spinal cord, even when the fistula itself is identified several levels above the lesion, presumably is due to orthostasis. ${ }^{12}$ Pathologically, development of changes secondary to venous congestion and stasis in the spinal cord parenchyma occurs, as described above. For this condition, the old term FoixAlajouanine syndrome has been used in the literature and in authoritative neuropathology textbooks. ${ }^{6,8-10}$ These authors described the two original patients in 1926 who presented with progressive paraplegia, sensory abnormalities, and 

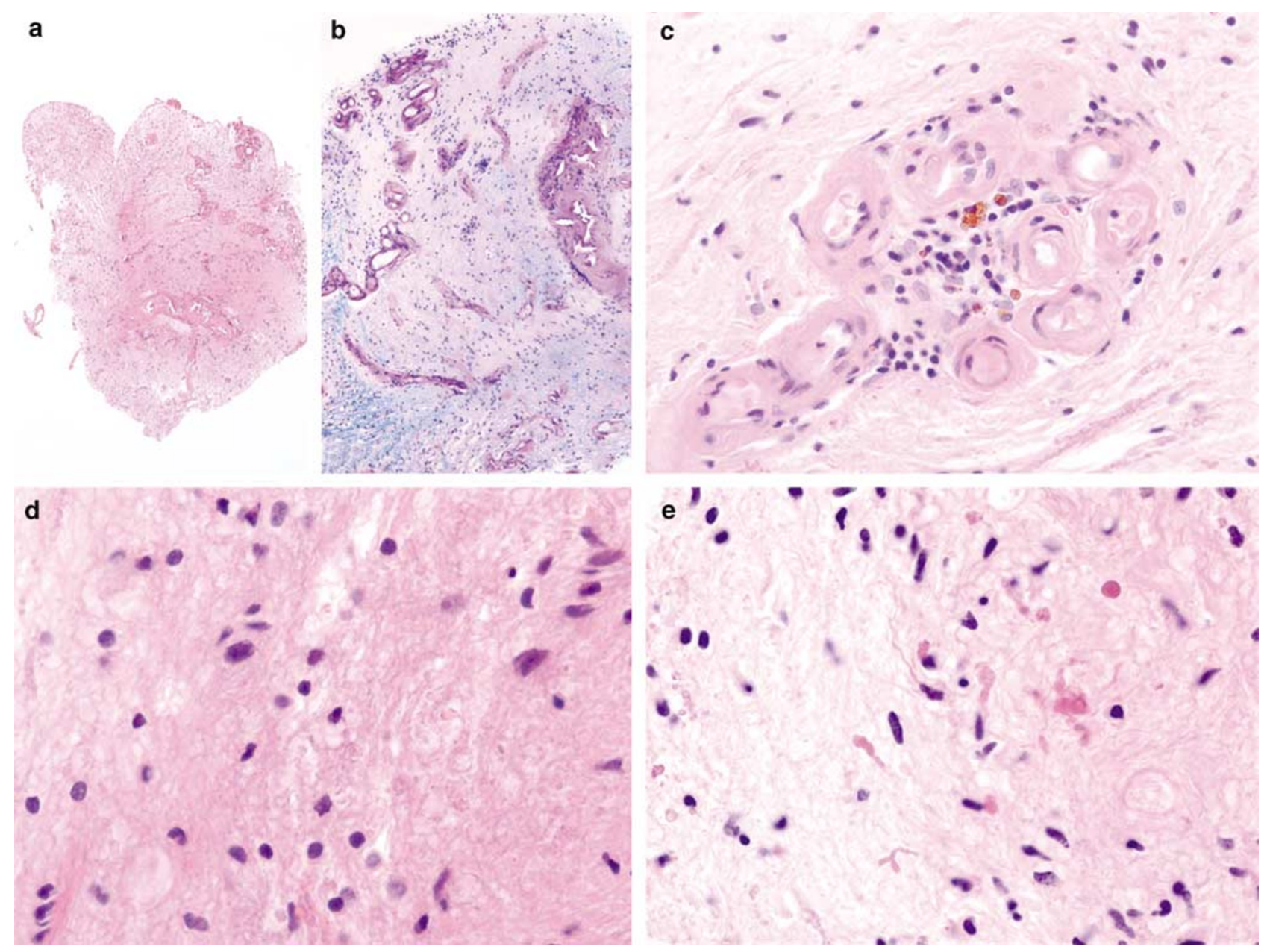

Figure 5 Patient 6: (a) Low-power view with increased number of small hyalinized vessels (H\&E, $\times 20)$. (b) LFB/PAS stain demonstrating thickened vessels and relative myelin loss $(\times 40)$. (c-e) High-power photomicrographs demonstrating a cluster of small hyalinized vessels with hemosiderin deposition (c), glial atypia (d), and Rosenthal fibers (e) $(\mathrm{H} \& \mathrm{E}, \times 600)$.

Table 2 Venous congestive myelopathy: histopathologic features

\begin{tabular}{|c|c|c|c|c|c|c|c|c|}
\hline Patients & Hyalinized vessels & Thrombosis & $\begin{array}{c}\text { Vessel wall } \\
\text { calcification }\end{array}$ & Hemosiderin & $\begin{array}{l}\text { Rosenthal } \\
\text { fibers }\end{array}$ & Necrosis & $\begin{array}{l}\text { Relative } \\
\text { myelin loss }\end{array}$ & $\begin{array}{l}\text { Mild glial } \\
\text { atypia }\end{array}$ \\
\hline 1 & + & + & - & + & - & $+1-$ & + & - \\
\hline 2 & + & - & - & - & + & - & + & + \\
\hline 3 & + & - & - & + & - & - & + & + \\
\hline 4 & + & + & - & + & - & + & - & + \\
\hline 5 & + & - & - & - & - & + & - & + \\
\hline 6 & + & - & - & + & + & - & + & - \\
\hline 7 & + & - & - & + & + & - & + & - \\
\hline$\%$ total & 100 & 29 & 0 & 71 & 43 & 29 & 71 & 57 \\
\hline
\end{tabular}

loss of sphincter control. Postmortem examination revealed markedly distended and tortuous intrathecal vessels, atrophy of the distal cord, necrosis, and proliferation of small hyalinized vessels, for which they used the term myelite necrotique subaigue (subacute necrotizing myelopathy). ${ }^{7}$ It was not until the 1970s, with continuous improvement in radiologic imaging, that the etiology of the majority of the cases was ascribed to a spinal dural arterio- venous fistula draining into intradural medullary veins. ${ }^{1,2}$ Large series of patients with this condition have been reported in recent decades. ${ }^{11,12,23}$ and their clinicoradiologic characteristics and therapeutic approaches have been well studied. Generally, the condition is suspected by the characteristic clinical syndrome and radiologic findings. The fistula is corrected surgically or by embolization, ${ }^{20,32}$ and spinal cord biopsy is usually not necessary. MRI 


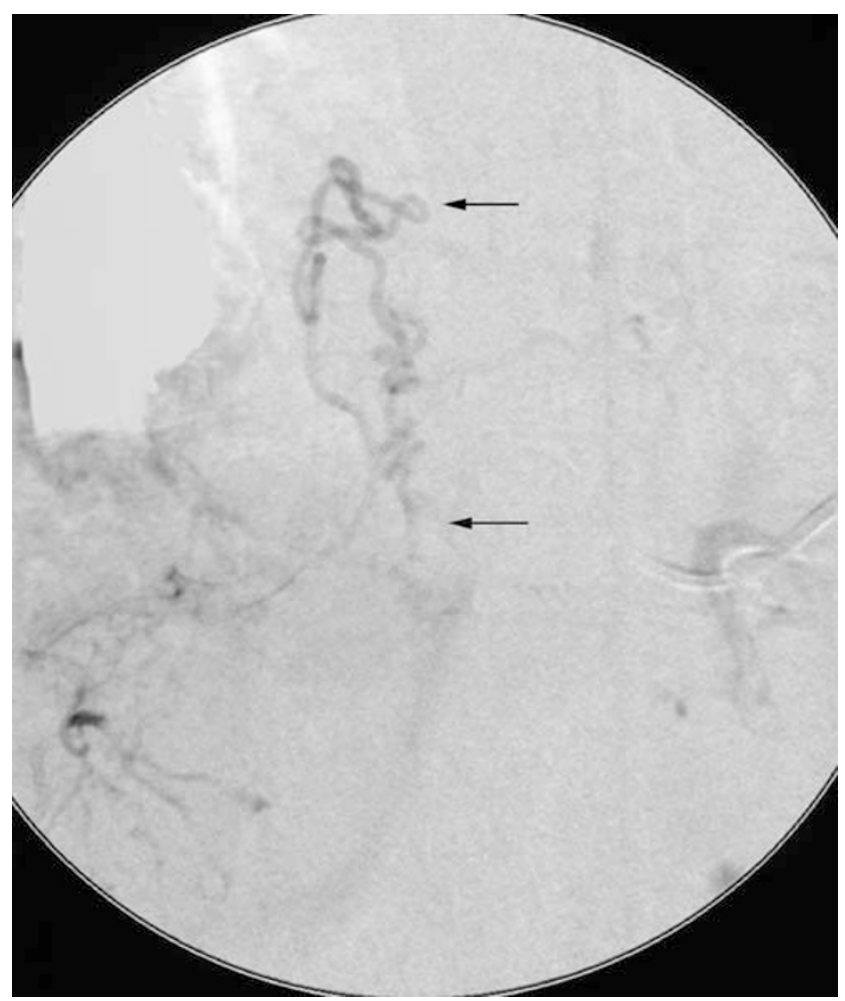

Figure 6 Patient 4: Spinal angiogram after selective injection of the right T10 intercostal artery demonstrates a draining arterialized intradural vein (top arrow) and the location of a dural arteriovenous fistula (bottom arrow).

characteristically shows spinal cord enlargement and T2 hyperintensity with variable contrast enhancement, ${ }^{10,11,15,17,19}$ often in the early course of the disease, features that are also present in spinal cord tumors. More specific signs, leading to a diagnosis of spinal dural arteriovenous fistula, include demonstration of serpentine vessels predominantly on the dorsal surface of the spinal cord, ${ }^{19}$ and probably the recently described peripheral spinal cord hypointensity by T2 sign. ${ }^{33}$

Occasionally, spinal cord biopsies from such cases may come to the surgical pathologist. The typical pathologic spinal cord findings have largely been described in older reports ${ }^{6-10,24,25}$ based on cases observed at autopsy, and without correlation with modern imaging techniques. Reports of the histologic findings of venous congestive myelopathy in spinal cord biopsies are scant. ${ }^{34}$

Not all cases with pathologic findings typical of venous congestive myelopathy appear to be associated with a spinal dural arteriovenous fistula. For example, Mirich et $a l^{15}$ reported four patients with preoperative MRI findings suggestive of tumor. A spinal cord biopsy was performed and morphology suggested venous congestive myelopathy as seen with an arteriovenous fistula; however, MRI and myelography demonstrated no abnormal vessels. The authors concluded that the changes may be an expression of a primary intramedullary vascular malformation, rather than one secondary to a spinal dural arteriovenous fistula. However, despite the presence of prominent veins identified intraoperatively overlying the cord in two of the four patients, no attempt was made to identify a fistula by spinal angiography. Similarly, Montine et $a l^{13}$ reported three patients with an abnormal MRI and histopathologic findings alike to those described above and concluded that the findings may be an expression of an isolated intramedullary spinal vascular malformation. In their cases, myelography and intraoperative inspection revealed no abnormal vessels; however, no angiographic studies were performed in any of the patients. Schwartz et $a l^{14}$ discussed two patients with an MRI suggestive of a spinal cord neoplasm and biopsy findings suggestive of venous congestive myelopathy. Spinal angiography and myelography were performed in one of the patients and revealed no fistula. The authors compared the histologic findings to those reported in venous congestive myelopathy associated with a spinal dural arteriovenous fistula. Unlike the latter, their biopsies lacked necrosis and featured greater vascular density than is typically seen in fistulaassociated cases. This conclusion would not be supported by the findings in our cases, in which the only difference between the patients with a demonstrable fistula and those without was microvascular thrombosis in the former (two of three patients). In our series, necrosis was noted in one patient in each group. In light of the three published series noted above, it is of interest that in ours, despite histopathologic findings typical of venous congestive myelopathy, a spinal dural arteriovenous fistula was demonstrated in only three of seven cases. Possible explanations for the absence of a demonstrable fistula are several, starting with the limitations of the studies used to identify the fistula. Indeed, the spinal dural arteriovenous fistula can be missed if complete selective spinal angiography (ie entire thoracic and lumbar, if needed) is not performed. Secondly, the fistula may be found distant from the site of cord signal abnormality, even being intracranial. ${ }^{35-37}$ In such cases, 4-vessel cerebral angiography must be performed, especially in those rare instances involving the cervical cord. Alternatively, feeder vessels supplying the fistula may originate in the pelvis. The demonstration of vessels supplying spinal dural arteriovenous fistulas may be compromised by atherosclerosis of segmental vessels ${ }^{35}$ or thrombosis of the draining veins. ${ }^{3}$

Venous congestive myelopathy can be a diagnostic challenge for the clinician and pathologist alike. As discussed above, the neuroimaging findings may lead to a preoperative misdiagnosis of neoplasia and result in a spinal cord biopsy. In those instances, the surgical pathologist plays an essential role in suggesting the possibility of a spinal dural arteriovenous fistula, a condition that may be treated leading to substantial recovery with a timely and accurate diagnosis. 


\section{References}

1 Aminoff MJ, Barnard RO, Logue V. The pathophysiology of spinal vascular malformations. J Neurol Sci 1974;23:255-263.

2 Kendall BE, Logue V. Spinal epidural angiomatous malformations draining into intrathecal veins. Neuroradiology 1977;13:181-189.

3 Criscuolo GR, Oldfield EH, Doppman JL. Reversible acute and subacute myelopathy in patients with dural arteriovenous fistulas. Foix-Alajouanine syndrome reconsidered. J Neurosurg 1989;70:354-359.

4 Kataoka H, Miyamoto S, Nagata I, et al. Venous congestion is a major cause of neurological deterioration in spinal arteriovenous malformations. Neurosurgery 2001;48:1224-1229.

5 Andersson T, van Dijk JM, Willinsky RA. Venous manifestations of spinal arteriovenous fistulas. Neuroimaging Clin N Am 2003;13:73-93.

6 Lhermitte J, Fribourg-Blanc, Kyriaco N. La gliose angeio-hypertrophique de la moelle epiniere (Myelite necrotique de Foix-Alajouanine)(French). Rev Neurol 1931;2:37-53.

7 Foix C, Alajouanine T. La myelite necrotique subaigue. (French) Rev Neurol 1926;11:1-42.

8 Girolami UD, Frosch MP, Tator CH. Diseases of the spinal cord and vertebral column. In: Graham DI, Lantos PL (eds). Greenfield's Neuropathology, 7th edn. Arnold Publishers: London, 2002, pp 1071-1074.

9 Koeppen AH, Barron KD, Cox JF. Foix-Alajouanine syndrome. Acta Neuropathol 1974;29:187-197.

10 Terwey B, Besinger U, Schuck M, et al. MR imaging related to p.m. findings in angiodysgenetic myelomalacia. A case report. Neurosurg Rev 1993;16:323-326.

11 Atkinson JLD, Miller GM, Krauss WE, et al. Clinical and radiographic features of dural arteriovenous fistula, a treatable cause of myelopathy. Mayo Clin Proc 2001;76:1120-1130.

12 Rosenbalum B, Oldfield EH, Doppman JL, et al. Spinal arteriovenous malformations: a comparison of dural arteriovenous fistulas and intradural AVMs in 81 patients. J Neursurg 1987;67:795-802.

13 Montine TJ, O'Keane JC, Eskin TA, et al. Vascular malformations presenting as spinal cord neoplasms: case report. Neurosurgery 1995;36:194-197.

14 Schwartz TH, Chang Y, Stein BM. Unusual intramedullary vascular lesion: report of two cases. Neurosurgery 1997;40:1295-1301.

15 Mirich DR, Kucharczyk W, Keller MA, et al. Subacute necrotizing myelopathy: MR imaging in four pathologically proved cases. Am J Neuroradiol 1991;12: 1077-1083.

16 Renowden SA, Molyneux AJ. Case report: spontaneous thrombosis of a spinal dural AVM (Foix-Alajouanine syndrome)-magnetic resonance appearance. Clin Radiol 1993;47:134-136.

17 Minami S, Sagoh T, Nishimura K, et al. Spinal arteriovenous malformation: MR imaging. Radiology 1988;169:109-115.

18 Saraf-Lavi E, Bowen BC, Quencer RM, et al. Detection of spinal dural arteriovenous fistulae with MR imaging and contrast-enhanced MR angiography: sensitivity, specificity, and prediction of vertebral level. Am J Neuroradiol 2002;23:858-867.
19 Gilbertson JR, Miller GM, Goldman MS, et al. Spinal dural arteriovenous fistulas: MR and myelographic findings. Am J Neuroradiol 1995;16:2049-2057.

20 Eskandar EN, Borges LF, Budzik RF, et al. Spinal dural arteriovenous fistulas: experience with endovascular and surgical therapy. J Neurosurg (spine 2) 2002; 96:162-167.

21 Schick U, Hassler W. Treatment and outcome of spinal dural arteriovenous fistulas. Eur Spine J 2003;12: 350-355.

22 Rodesch G, Lasjaunias P. Spinal cord arteriovenous shunts: from imaging to management. Eur J Radiol 2003;46:221-232.

23 Symon L, Kuyama H, Kendall B. Dural arteriovenous malformations of the spine. Clinical features and surgical results in 55 cases. J Neurosurg 1984;60: 238-247.

24 Wyburn-Masson W. The Vascular Abnormalities and Tumours of the Spinal Cord and its Membranes. Mosby: St Louis, 1944, pp 7-25.

25 Jellinger $\mathrm{K}$. Vascular malformations of the central nervous system: a morphological overview. Neurosurg Rev 1986;9:177-216.

26 Marsh WR. Vascular lesions of the spinal cord: history and classification. Neurosurg Clin N Am 1999;10:1-8.

27 Borden JA, Wu JK, Shucart WA. A proposed classification for spinal and cranial dural arteriovenous fistulous malformations and implications for treatment. J Neurosurg 1995;82:166-179.

28 Rodesch G, Hurth M, Alvarez H, et al. Classification of spinal cord arteriovenous shunts: proposal for a reappraisal-the Bicetre experience with 155 consecutive patients treated between 1981 and 1999. Neurosurgery 2002;51:374-379.

29 Spetzler RF, Detwiler PW, Riina HA, et al. Modified classification of spinal cord vascular lesions. J Neurosurg 2002;96(2 Suppl):145-156.

30 Pirouzmand F, Wallace MC, Willinsky R. Spinal epidural arteriovenous fistula with intramedullary reflux. Case report. J Neurosurg 1997;87:633-635.

31 Grote EH, Voigt K. Clinical syndromes, natural history, and pathophysiology of vascular lesions of the spinal cord. Neurosurg Clin N Am 1999;10:17-45.

32 Caragine Jr LP, Halbach VV, Ng PP, et al. Vascular myelopathies-vascular malformations of the spinal cord: presentation and endovascular surgical management. Semin Neurol 2002;22:123-132.

33 Hurst RW, Grossman RI. Peripheral spinal cord hypointensity on T2-weighted MR images: a reliable imaging sign of venous hypertensive myelopathy. Am J Neuroradiol 2000;21:781-786.

34 Hurst RW, Kenyon LC, Lavi E, et al. Spinal dural arteriovenous fistula: the pathology of venous hypertensive myelopathy. Neurology 1995;45:1309-1313.

35 Wrobel CJ, Oldfield EH, Di Chiro G, et al. Myelopathy due to intracranial dural arteriovenous fistulas draining intrathecally into spinal medullary veins. Report of three cases. J Neurosurg 1988;69:934-939.

36 Perkash I, Punj V, Ota DT, et al. Intracranial dural arteriovenous fistula causing a myelopathy. Spinal Cord 2002;40:438-442.

37 Kalamangalam GP, Bhattacharya J, Teasdale E, et al. Myelopathy from intracranial dural arteriovenous fistula. J Neurol Neurosurg Psychiatr 2002;72:816-818. 